\title{
The importance of media literacy education: How Lithuanian students evaluate online news content credibility
}

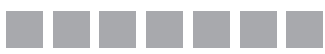

Andrius Šuminas

ORCID: 0000-0003-0384-2011

VILNIUS UNIVERSITY, LITHUANIA

Deimantas Jastramskis

ORCID: 0000-0001-8439-5297

VILNIUS UNIVERSITY, LITHUANIA

https://doi.org/10.19195/1899-5101.13.2(26).5

\begin{abstract}
Nowadays, when the flow of fake news in traditional media and on social media platforms has increased dramatically, media and information literacy (MIL) skills are more important than ever. MIL promotes the critical thinking skills that enable people to make independent choices, in particular how to evaluate and choose different information sources and channels, as well as how to interpret the news and information received through those channels. This article explores how young people in Lithuania evaluate the trustworthiness of news. Two groups of students were selected for the experiment: young people who had participated in a basic course in MIL, and young people whose learning was minimally related to MIL. The study was conducted using a survey and eye-tracking device that enabled researchers to record and analyse readers' real behaviour and to identify the distribution of attention, i.e. the concentration of sight and time spent on particular news elements. The research results show a clear difference between these two groups and thus confirm the importance of media literacy education.
\end{abstract}

KEYWORDS: media literacy, news trustworthiness, news literacy, eye tracking, Lithuania

* This work received support from the European Union ERASMUS+ Strategic Partnership project "Media and Information Literacy \& Innovative Teaching Methods Laboratory" No. 2017-1-LV01KA203-035429. 


\section{INTRODUCTION}

The importance of media literacy education is widely discussed in scientific literature from various perspectives as it has numerous applications within different contexts (Schmidt, 2013). Due to fact that it includes the diversity of dimensions - i.e. technological, culture, social, and economic - it might be called "an umbrella concept" (Koltay, 2011) and has been the subject of manifold definitions. Over the years, the main focus of media literacy has been on print and audiovisual media and peoples' skills regarding how to practically exploit those traditional communication channels.

The role of media literacy education is emphasised especially in the context of young people's education. Despite the fact that young people use new technologies and forms of communication with ease, they do not necessarily have the abilities to fully analyse and evaluate media content. Media literacy helps young people to understand media content correctly, to critically dissect media forms, and consequently to benefit from media intelligently.

Although media literacy has mostly been applied to K-12 education, undeniably it is vital to help individuals of all ages acquire the competencies necessary to fully participate in the modern world of media convergence (Schmidt, 2012). Due to all these reasons, media literacy educational programmes and research have both grown significantly (Hobbs, 2005, 2011; Potter, 2010; Schmidt, 2013). Existing media literacy studies have focused primarily on programmes geared towards children and teenagers, especially at the K-12 level (Hobbs, 1998; Mihailidis, 2008; Martens, 2010) and less recognised are the issues related to the media literacy topics in the context of postsecondary higher education (Schmidt, 2013). Universities and other higher education institutions increasingly offer media literacy courses; in some cases it is possible to even find study programmes dedicated to media literacy. The necessity of media literacy in the university curriculum is reasoned from a cultural studies perspective and is emphasised in the importance of the impact of media usage on "lived society" (Onge, 2018, p. 15). Although media literacy competencies are not only addressed during media literacy courses, associated competencies can also be addressed in an interdisciplinary fashion in a wide range of courses across the university-level curriculum (Ashlock, 2011; Schmidt, 2013).

It would be beneficial to continue developing the $\mathrm{K}-12$ and university partnership, enhancing the cultivation of media literacy competencies in the curriculum (Butler, 2018). On the other hand, the significance of media and information literacy (MIL) in university education becomes more important when this subject is fragmented and partly based on volunteer project activities in secondary education. This is relevant for the Baltic States and for Lithuania in particular (Balčytienė \& Juraité, 2017), where MIL education as informal practical activities was incorporated into a general education curriculum for primary and secondary education (and the Lithuanian government began strategically to plan the training of teachers for MIL integration into 
preschool, primary, and secondary education) only from 2017 (Order of the Minister of Education and Science of the Republic of Lithuania No V-442, 2017).

Media literacy education is extremely important for journalism students because, after finishing their studies, as journalists, they are going to be responsible for media content. Katherine G. Fry (2018, p. 14) argues for the necessary inclusion of digital media literacy into curriculum related to television and radio in the context of a "paradigm shift in the existing media landscape". A media literate perspective could improve journalism practices by providing journalism students with a more holistic knowledge of message construction and reception. When journalists attain insights into how texts are interpreted, used, and enjoyed by audiences, they may gain proficiency in storytelling from the production side (Mihailidis, 2006). Also, sophisticated MIL education will prevent future journalists from getting lost in the sea of public relations, content marketing, and misinformation.

The issue of raising the level of journalism by providing sufficiently literate representatives of this profession is of vital importance in times called by many the era of post-truth. Jason Tanz in his article entitled "Journalism Fights for Survival in the Post-Truth Era" (Wired, February 14, 2017), concluded: "In a post-fact era of fake news and filter bubbles, in which audiences cherry-pick the information and sources that match their own biases and dismiss the rest, the news media seems to have lost its power to shape public opinion." If this opinion should not became a prophecy, if journalists should still "occupy the symbolic communicative centre of democracies through normative goals of information production and dissemination" (Carlson, 2018, p. 1182), there is a need for wide research in the area of media and information literacy, the results of which will influence journalism educational curricula.

In this article, we examine the media literacy level of students, focusing on the process of news evaluation. The objective of our article is to ascertain the impact of media literacy education on the evaluation of news credibility. Starting with an outline of media literacy, we discuss the relationship between journalism and MIL and conceptualize the news evaluation regarding its credibility. As the systematic MIL education at the K-12 level in Lithuania does not matter, we seek to find out the ability of journalism and other students (with different MIL education at university) to assess and argue for news credibility. The empirical part includes a survey and experiment with an eye-tracking device that enables to identify the distribution of attention of participants on particular news elements.

\section{MIL AND NEWS EVALUATION}

It is worth remembering that in early definitions the general notion of literacy was described as "social practices and conceptions of reading and writing" (Street, 1984). Only later did researchers like Aufderheide and Firestone (1993, p. 7), who generally defined media literacy as "the ability to access, analyse, evaluate and communicate messages in a wide variety of forms", make an effort to define precisely such a complex 
concept as media literacy (and others literacies like information literacy or digital literacy) and start to consider a wider range of skills, such as analysing and evaluating (Masterman, 1985; Messaris, 1994). In recent decades, within both academic and policy discourses, the concept of media literacy has been being extended from its traditional focus on print and audiovisual media to encompass new media on the internet (Livingstone, 2004). In light of the fast-changing media landscape, it has been widely acknowledged that people need to develop new media-related competencies that will allow them to function successfully in the world of the present and future.

Therefore, media literacy skills are essential in terms of educating people to become more critically aware of the media they consume so that they can protect themselves from unsuitable messages, have a better understanding of the media, and experience enhanced enjoyment (Potter, 2008). Media literacy is increasingly becoming an important component of European and national policy agendas in the media and communication sectors. Media literacy on a political level is generally defined as the ability to access the media, to understand and to critically evaluate different aspects of the media and media contents, and to create communications in a variety of contexts (European Commission, 2007). According to the European Commission (2007), the various levels of media literacy include:

- feeling comfortable with all existing media from newspapers to virtual communities;

- actively using media, through, inter alia, interactive television, use of internet search engines or participation in virtual communities, and better exploiting the potential of media for entertainment, access to culture, intercultural dialogue, learning, and daily-life applications (for instance, through libraries and podcasts);

- having a critical approach to media as regards both quality and accuracy of content (for example, being able to assess information, dealing with advertising on various media, using search engines intelligently);

- using media creatively, as the evolution of media technologies and the increasing presence of the internet as a distribution channel allow an ever-growing number of Europeans to create and disseminate images, information, and content;

- understanding the economy of media and the difference between pluralism and media ownership;

- being aware of copyright issues which are essential for a "culture of legality", especially for the younger generation in its double capacity of consumers and producers of content (today's society is bombarded with messages from different media channels, so understanding media and being able to analyse those messages critically is the necessary skill required for being media literate).

According to more present-day definitions of literacy, literacy involves gaining the skills and knowledge to read and interpret varying texts and artefacts, and to successfully navigate and negotiate their challenges, conflicts, and crises (Kellner \& Share, 2005). Media literacy, in turn, refers to the understanding of media and the 
use of it as a source of information, entertainment, enrichment, growth, empowerment, and communication (Wan, 2006; Wan \& Gut, 2008).

Due to critical thinking and evaluation having become crucial skills for literacy, the notion of critical media literacy has appeared. Its aim is to expand the notion of literacy to include different forms of media culture, information and communication technologies, and new media, as well as deepening the potential of literacy education to critically analyse relationships between media and audiences, information, and power (Kellner \& Share, 2007). A critical approach as part of literacy is also crucial in the context of controversies around potential social media use - the advantages of participation and empowerment on one hand and shallow relationships, consumerism, exploitation, and safety and on the other (Burnett \& Merchant, 2011).

Critical media literacy incorporates three stages that lead to the empowerment of citizens of all ages: (a) becoming aware of the importance of making choices and managing the amount of time spent with various media forms; (b) learning specific skills of critical viewing and surfing - learning to analyse and question what is in the frame/on the screen, how it is constructed, and what may have been left out; and (c) exploring deeper issues of who produces the media that people experience and for what purposes (Thoman, 1995; Wan \& Gut, 2008).

When examining the relationship between journalism and MIL, we must first focus on news literacy which is at the intersection of information literacy and media literacy (Malik et al., 2013). News is the journalistic product and the result of the work of humans (or artificial intelligence under their control) in the selection, evaluation, and preparation of certain information that must be new or partially new and has not yet been disclosed. In order for the audience to identify the news as the appropriate content, they must be news literate and, above all, develop critical thinking and communication skills to recognise news and events in the modern communication landscape (Hobbs, 2010). A broader view of news literacy should include an understanding of the role of news and journalism in society and democracy. It is even important for young people to develop their motivation to seek out news and be interested in the news. Creators of journalistic content (news) must develop professional skills for the production of the news (the best way to learn about the structure of news for citizenjournalists and informed consumers also) (Malik et al., 2013). In reality, the ability to create journalistic content cannot be decoupled from all the other abilities mentioned above. It is a composite set of attributes that make up news literacy complexity.

Each editorial staff, when creating news content, follows certain selection criteria for the information, as well as evaluating the credibility of the information received and the sources that provide it. According to the theory of social responsibility, the media organisation which carries out economic activities must be socially responsible, and therefore it must prepare and disseminate true, accurate, fair, relevant, and objective news (McQuail, 2010). The concept of "objectivity" is discussed as one of the most important concepts in journalism theory; it is closely connected to the quality of news information. To achieve objectivity in news, it 
is essential that its contents meet the main criteria of objectivity: factuality and impartiality as well as their criteria of truth, relevance, newsworthiness, balance, and neutrality (Westerstahl, 1983). In news, to report on an individual fact and its relevance to reality would suffice to satisfy the criterion of truth only and to equate fair reporting with objectivity. The primary component of objectivity - factuality and fact-checking - has been the domain of responsible journalists and editors for decades. However, as the internet and social media evolved, the audience was flooded with a lot of unverified, misleading, or false information packaged with news etiquette, and the need for additional fact-checking increased. Some editorial offices have created new sections for fact-checking or truth-finding, though this has always been and is the essence of journalistic work. A certain fact-checking rebranding has taken place with appropriate public communication. Even factchecking groups and movements have been set up, which, according to Graves (2016, p. 6) "seek to revitalise the 'truth-seeking' tradition in journalism". In this way, a double fact-checking scheme has been launched: before and after the news was published. Some tasks of the fact-checking have been enhanced by automated methods. Even though computational fact-checking helps to process much of the information needed to determine the truth, computer validation itself is based on facts that have already been validated by humans (Hassan et al., 2015; Nguyen et al., 2019; Shi \& Weninger, 2016). As a result of the problem of verifying new facts, which is commonplace in journalism, human resources remain at the heart of decision-making about facts.

The scheme of objectivity must be extended due to a great many events in an individual news item and different approaches to reporting facts, the criteria for the selection of prominent facts, and the balance between fact and opinion (McQuail, 2010). The content of a news item that is factual and is clearly constructed, important, and comprehensive can communicate certain values that are promoted by the participants of the event, journalists, or media organisations. Since it is not always possible for subjects (participants, journalists, and the audience) to distance themselves from their subjectivity, it is important to make the most of seeking balanced and neutral reporting, i.e. impartiality, to construct a news item in accord with the principle of objectivity.

Critics of the doctrine of objectivity in journalism see objectivity itself as a kind of bias or even myth and ideology (Glasser, 1992; Maras, 2013; McQuail, 2010). However, such criticism is usually related to the different treatment of objectivity and its misapplication in practice. On the contrary, the pursuit of objectivity and journalistic procedures relating to the selection of sources, fact-checking, and balance of views help to ensure the credibility of the news. And in that way, "objectivity safeguards credibility while diffusing concerns about bias" (Maras, 2013, p. 56) with respect to news.

What makes certain facts and news about an event credible to an audience who did not attend a particular event and who must rely on its presentation in the media? Metzger et al. (2003) indicate three levels of information credibility: source, message, and media. Source credibility is usually defined by expertise and 
trustworthiness, whereby expertise refers to a qualified expert on the topic, and trustworthiness is conceptualised as the motivation of the communicator to tell the truth about the topic (Hovland et al., 1953; Metzger et al., 2003). References to sources indicate where the facts come from and what persons or documents are cited. The credibility of the news can be judged by the credibility of the sources. When sources are not identified or named without explaining why they are not disclosed, the information cannot be considered credible because its origin is not clear. If the journalist explains the circumstances of the source's confidentiality and uses such a tool in exceptional cases, the news may be considered credible (subject to some reservations) until the accuracy of the information provided becomes clear as a result of the new facts presented.

When assessing the credibility of a news item, it is important to know who the author of the news is: whether it is a specific person, editorial office, or news agency (Sakadolskis, 2007). This is basically the aforementioned level of media credibility. Failure to indicate authorship implies no responsibility for the content of the information and may cause distrust among the critical audience. If the content is said to have be produced in association with or on the initiative of the information partner, this implies that the editorial office is not responsible for the information provided and thus it is left to the audience to decide on the trustworthiness of the information.

Another problematic and rather widespread case of source/authorship in the media is when the only source of information is identified by a public authority or business entity (sometimes these entities are referred to as authors), and the news is "created” by a copy-paste method from a particular press release. These are cases of so-called information subsidies in the media where information from the source to the editorial office is delivered directly to gain access to the media audience (Lilleker, 2006). Depending on the facts presented and the credibility of the author of the subsidy, the trustworthiness of the information must also be assessed. This is the so-called grey zone of media content, where the credibility of information can only be partial and questionable.

When considering credibility at the message level, it should first be emphasised that professionally produced news must answer at least four questions: Who? What? When? Where? If at least one of the four questions in news journalism is not answered, the news will be lacking in essential information and will not be considered as trustworthy (Sakadolskis, 2007). The broader context of the event and the reasons behind it also require answering the questions: How? Why? When it comes to news genres, it should also be emphasised that facts must be distinguished from the opinions quoted. Given the element of impartiality in the concept of objectivity and the criterion of balance, it is necessary to include in the news the views of all the major players in the event and to ensure the diversity of sources so that the audience can understand the event in detail. 


\section{RESEARCH QUESTIONS}

Our research aimed to empirically assess the impact of media (news) literacy education on the process of evaluating the news. We employed a comparative approach and first asked what the differences are in the assessment of news credibility between young people who have a fairly solid (journalism students) versus minimal (publishing and advertising students) background in news literacy. It was also important to examine the arguments used to evaluate the credibility of the news and to find out whether the news credibility criteria are applied in the evaluating process or more random statements are used for argumentation. To supplement the research data on the reasoning behind the news credibility assessment, we sought to determine what elements of the news users pay more attention to when assessing the credibility of the news.

\section{METHODOLOGY}

To achieve the aim of the research, we decided to run the experiment with university students since we were trying to understand in a practical way how young people evaluate the trustworthiness of news. Two research groups of Vilnius University students were selected for the research - young people who have participated in various basic courses dealing with media and information literacy (second-year, fourth semester BA journalism students) and young people whose learning was minimally related to news literacy (second-year, fourth semester BA publishing and advertising (PA) students).

Table 1 presents a comparison of news literacy education between two groups of students according to the four dimensions of news literacy proposed by Malik et al. (2013): 1) an understanding of the role news plays in society, 2) the ability to find/identify/recognise news, 3) the ability to critically evaluate news, and 4) the ability to create news. Two or three course units cover all four news literacy dimensions in the journalism curriculum. Meanwhile, only one course unit focuses on one news literacy dimension (the understanding of the role news plays in society) in the publishing and advertising curriculum. The course units of three semesters of both study programmes were analysed because participants of the research experiment were fourth-semester students.

For the purposes of the experiment, we prepared three news articles in order to make them look as visually similar as possible to real online news pieces. To prepare the news articles for the research, we used the material from various news organisations and the Media Centre of the President of the Republic of Lithuania. All three news articles were connected with the Lithuanian President Dalia Grybauskaite: news article No. 1 - The President of Lithuania discussed the formation of the new EU budget with Donald Tusk; news article No. 2 - The President proposes to increase fines for misleading advertising; news article No. 3 - Local Poles were disappointed with President Duda's visit to Lithuania. All three articles had a photo of Lithuanian President Dalia Grybauskaite (one together with Polish President Andrzej Duda). 
Table 1. Course units related to news literacy in curricula

\begin{tabular}{|l|l|l|}
\hline \multicolumn{1}{|c|}{ Dimension of news literacy } & $\begin{array}{c}\text { BA course units (number of } \\
\text { ECTS) in the journalism study } \\
\text { curriculum }\end{array}$ & $\begin{array}{c}\text { BA course units (number of } \\
\text { ECTS) in the publishing and } \\
\text { advertising study curriculum }\end{array}$ \\
\hline $\begin{array}{l}\text { To understand the role news } \\
\text { plays in society }\end{array}$ & $\begin{array}{l}\text { Introduction to Journalism (5) } \\
\text { News Journalism (4) } \\
\text { Political Communication } \\
\text { Theory (4) }\end{array}$ & $\begin{array}{l}\text { Political Communication and } \\
\text { Civil Society (5) }\end{array}$ \\
\hline $\begin{array}{l}\text { To find/identify/recognise } \\
\text { news }\end{array}$ & $\begin{array}{l}\text { Introduction to Journalism (5) } \\
\text { News Journalism (4) }\end{array}$ & \\
\hline To evaluate news critically & $\begin{array}{l}\text { Introduction to Journalism (5) } \\
\text { News Journalism (4) } \\
\text { Genres of Journalism (4) }\end{array}$ & - \\
\hline To create news & $\begin{array}{l}\text { News Journalism (4) } \\
\text { Genres of Journalism (4) }\end{array}$ & \\
\hline
\end{tabular}

Note: It is important to note that the vast majority of our research respondents were women: second-year BA journalism students $\mathrm{N}=20$ (women-15, men-5); second-year BA publishing and advertising students $\mathrm{N}=20$ (women-18, men-2).

Source: Information system of Vilnius University.

\title{
Vietos lenkai nusivylè prezidento A. Dudos vizitu Lietuvoje
}

\begin{abstract}
Prezidentė Dalia Grybauskaitè susitiko su Lenkijos Prezidentu Andrzejumi Duda. Susitikimo išvakarèse Lenkijos vadovas dalyvavo Vasario 16-osios valstybès atkūrimo 100-mečio iškilminguose renginiuose, taip pat susitiko su lenkų tautinès mažumos atstovais Lietuvoje.
\end{abstract}
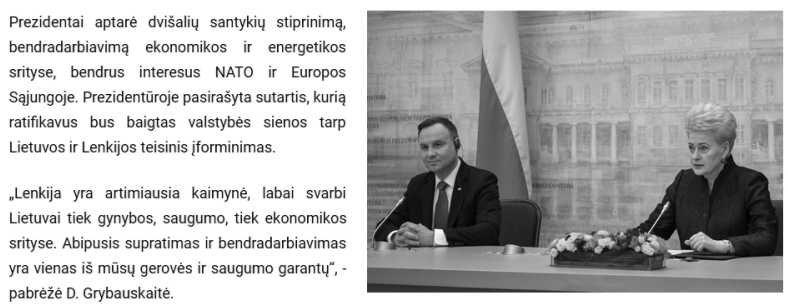

Aptariant tautinių mažumų klausimus, D. Grybauskaité pasiūlè atnaujinti dvišalès šveitimo komisijos darbą ir pabréžé, jog stiprèjantis politinis geranoriškumas iš abieju pusių sudarys galimybes išspręsti jautrius tautinių mažumų klausimus tiek Lietuvoje, tiek Lenkijoje.

Tačiau lenkụ tautines mažumos atstovai Lietuvoje nusivylè Lenkijos prezidento Andrzejaus Dudos vizitu Lietuvoje. Nejivardinti vietos lenku atstovai teigé, jog A. Duda siekdamas geopolitiniu Lenkijos tikslų nuolaidžiavo Lietuvos prezidentei ir per mažai démesio skyrè lenkų tautinés mažumos problemoms mūsų šalyje.

Figure 1. Example of the news article used in the study

As shown in Table 2, the trustworthy article used in the study had all the hallmarks of credible news media content - headline and lead, named author, photo caption, and two different named sources (news agency sources). Another article, 
which was an untrustworthy one, was prepared according to an example of fake news, where some real facts and information are mixed with fictive and fake elements. In our case, this article was missing a named author, a photo caption, and real information about Polish President Andrzej Duda's visit to Lithuania. Furthermore, a fictitious negative comment given by the undisclosed representatives of the local Polish minority in the country was mixed in. The third news article selected for the research belonged to the "partly trustworthy" category. It was a typical version of a one-source information subsidy put together by an editorial office from the press release of the Media Centre of the President of the Republic of Lithuania.

Table 2. Elements of the research articles used in the study

\begin{tabular}{|l|c|c|c|}
\hline \multicolumn{1}{|c|}{ News item } & $\begin{array}{c}\text { No. 1 } \\
\text { Trustworthy }\end{array}$ & $\begin{array}{c}\text { No. 2 } \\
\text { Partly trustworthy }\end{array}$ & $\begin{array}{c}\text { No. 3 } \\
\text { Untrustworthy }\end{array}$ \\
\hline Headline & + & + & + \\
\hline Author & + & + & - \\
\hline Lead & + & + & + \\
\hline Photo & + & + & + \\
\hline Photo caption & + (with author) & + (without author) & - \\
\hline Sources & 2 & 1 & 2 (1-unnamed) \\
\hline
\end{tabular}

Source: Authors.

Students from both research groups (20 people in each group) were asked to evaluate the trustworthiness of the abovementioned news articles. We wanted to find out whether there were any differences between the performance of the students who had been enrolled in various media and information literacy courses (second-year BA journalism students) and the students whose learning was minimally related to news literacy (second-year BA publishing and advertising students). It was also important to determine on which news items a person focused attention while evaluating news trustworthiness and to determine on what grounds the evaluation of the trustworthiness of news took place.

In the course of the experiment, we asked each respondent to evaluate the trustworthiness of the news articles one by one. All three news articles were presented on a large laptop (19") monitor. The time for reading news articles was not limited. The respondents were informed in advance that they had to click on a specific news article every time they made a decision.

In order to get a better understanding of the profile of our respondents, we asked some additional questions before and after the experiment. The questions asked before the experiment included demographic characteristics, such as gender and age, and information about the respondents' news and media consumption habits. Giving answers to additional questions on a laptop before the main experiment 
also made the respondents comfortable with the system. After the experiment was over, we sought to explain how the respondents evaluated a particular news article.

In order to find out the respondents' basic gazing data (focus points, entry points, reading paths, and time spent), we used a mobile eye-tracking laboratory set up at the Vilnius University Faculty of Communication building. The respondents were placed in front of a laptop with the eye-tracking equipment mounted (Tobii X2-30 Eye Tracker), and the eye-tracking software (Tobii Studio 3.2) installed in it. A second monitor was connected and used for a live preview of the respondent's actions. I-VT fixation filter with a velocity threshold of $20 \mathrm{~ms}$ was used. The minimum fixation duration was set to $60 \mathrm{~ms}$, adjacent fixations were merged if they did not exceed $75 \mathrm{~ms}$, and an angle of 0.5 degrees was used between fixations.

Some measures were taken in order to answer the research questions. The time to the first fixation, counted in milliseconds, was measured and was used as an indicator for the respondent's first fixation on a specific area of interest. This metric, when compared to other areas of interest, showed which elements of the news article were drawing more user attention in the context of the task they were asked to perform. The number of fixations on a specific news article was measured for each participant as a fixation count and served as an indicator of the elements with the longest or shortest time of looking at a specific place. A mouse click count was used to measure the task completion duration from the beginning of the experiment to the moment the user finished the evaluation and clicks on the article.

\section{RESULTS}

The research respondents spent most of their time reading and evaluating the news article which belonged to the "partly trustworthy" category. The average time used to evaluate the partly trustworthy news item was 83.1 seconds; it was 71.1 seconds in the case of the trustworthy news item, and 67.5 seconds in the case of the untrustworthy news item (Table 3 ). The time was calculated from the moment when the news articles were presented to the respondent until the mouse click, which marked the end of the evaluation process.

Table 3. Average evaluation time for research news items (seconds)

\begin{tabular}{|l|c|c|c|}
\hline & Trustworthy & Partly trustworthy & Untrustworthy \\
\hline Journalism students & 70.6 & 86.5 & 68.9 \\
\hline $\begin{array}{l}\text { Publishing and advertising } \\
\text { students }\end{array}$ & 71.6 & 79.7 & 66.1 \\
\hline All respondents & 71.1 & 83.1 & 67.5 \\
\hline
\end{tabular}

Source: Authors. 
Table 4. Evaluation of trustworthy news and reasoning for why the news should be trustworthy, partly trustworthy or untrustworthy (\%)

\begin{tabular}{|l|c|c|}
\hline \multicolumn{1}{|c|}{ Evaluation and reasoning } & Journalism students & $\begin{array}{c}\text { Publishing } \\
\text { and advertising students }\end{array}$ \\
\hline Trustworthy & $\mathbf{8 5}$ & $\mathbf{5 5}$ \\
\hline Specified sources & 40 & 10 \\
\hline Facts & 25 & 15 \\
\hline Convincing information & - & - \\
\hline $\begin{array}{l}\text { Appropriate presentation } \\
\text { of information }\end{array}$ & 10 & 5 \\
\hline Reliability of media outlet & 10 & 5 \\
\hline $\begin{array}{l}\text { Information about the } \\
\text { head of state }\end{array}$ & - & 5 \\
\hline Quoting & - & $\mathbf{4 0}$ \\
\hline Partly trustworthy & $\mathbf{1 5}$ & 5 \\
\hline Specified sources & - & 10 \\
\hline Lack of fact & 5 & 5 \\
\hline Grammatical inaccuracies & 5 & 20 \\
\hline Don't know & - & 5 \\
\hline Untrustworthy & - & 5 \\
\hline Grammatical inaccuracies & - & 5 \\
\hline
\end{tabular}

Source: Authors.

Respondents needed the least time for the evaluation process in a case of the untrustworthy news material, the longest evaluation was of partly trustworthy news. However, it is important to notice that during the course of the experiment the respondents were first presented with the partly trustworthy news article, after the untrustworthy piece, and the last one was trustworthy news article. This could have had a direct impact on the time respondents needed to evaluate all three news articles.

The survey data in Table 4 suggest that the group of journalism students evaluated the text of trustworthy news much more accurately than the group of PA students. Respectively, $85 \%$ of the journalism students and $55 \%$ of the PA students provided correct evaluations regarding the piece of trustworthy news. However, $40 \%$ of the PA students and 15\% of the journalism students evaluated the trustworthy news as partly trustworthy, and 5\% of the PA students evaluated it as untrustworthy. 
Table 5. Evaluation of partly trustworthy news and reasoning for why the news should be trustworthy, partly trustworthy or untrustworthy (\%)

\begin{tabular}{|l|c|c|}
\hline \multicolumn{1}{|c|}{ Evaluation and reasoning } & Journalism students & $\begin{array}{c}\text { Publishing } \\
\text { and advertising students }\end{array}$ \\
\hline Trustworthy & $\mathbf{4 0}$ & $\mathbf{5 0}$ \\
\hline Facts & 25 & 50 \\
\hline Convincing information & 10 & 5 \\
\hline Don't know & $\mathbf{5 0}$ & $\mathbf{4 5}$ \\
\hline Partly trustworthy & 15 & 5 \\
\hline Lack of sources & - & 5 \\
\hline Specified sources & 5 & 5 \\
\hline Lack of facts & - & 5 \\
\hline Convincing information & 15 & 5 \\
\hline Unreliability of media outlet & 15 & 20 \\
\hline Don't know & $\mathbf{1 0}$ & $\mathbf{5}$ \\
\hline Untrustworthy & 5 & - \\
\hline Unreliability of media outlet & 5 & 5 \\
\hline Don't know & & 5 \\
\hline
\end{tabular}

Source: Authors.

We can also see essential differences regarding the reasoning for the evaluation of trustworthy news between these two groups of students. Seventy-five percent of the journalism students appealed to specified sources, facts, and the appropriate presentation of information according to the standards of journalism in assessing the trustworthiness of the information. However, only $25 \%$ of the PA students evaluated the trustworthiness of news by citing specified sources and provided facts. Moreover, $15 \%$ of the PA students used the argument of convincing information to justify the news trustworthiness. Being convincing is inherent in defining advertising communication but not news. It is also important to emphasise that $20 \%$ of the PA students did not know why they labelled the trustworthy news as partly trustworthy (when only $5 \%$ of the journalism students gave such assessment).

The trends seen in Table 5 suggest very similar results regarding the assessment of partly trustworthy news and the reasoning for why the news should be trustworthy, partly trustworthy, or untrustworthy in both groups of the sample. The press release of the state institution (published as original news by the editorial staff of the media outlet) was evaluated as partly trustworthy news by half 
of the journalism students and almost half (45\%) of the PA students. However, very few respondents (altogether $20 \%$ of the journalism students and $10 \%$ of the PA students) explained such a choice by the lack of sources or facts. Moreover, the unilateral presentation of facts was an "appropriate" argument to render the partly trustworthy news as trustworthy for $25 \%$ of the journalism students and $40 \%$ of the PA students. Besides, $30 \%$ of the students overall in both groups did not know why they mentioned that a piece of information should be trustworthy, partly trustworthy, or untrustworthy.

Table 6. Evaluation of untrustworthy news and reasoning for why the news should be trustworthy, partly trustworthy or untrustworthy (\%)

\begin{tabular}{|l|c|c|}
\hline \multicolumn{1}{|c|}{ Evaluation and reasoning } & Journalism students & $\begin{array}{c}\text { Publishing } \\
\text { and advertising students }\end{array}$ \\
\hline Trustworthy & $\mathbf{1 5}$ & $\mathbf{2 5}$ \\
\hline $\begin{array}{l}\text { Information about the head } \\
\text { of state }\end{array}$ & 5 & 5 \\
\hline Convincing information & - & 5 \\
\hline Quoting & 5 & 5 \\
\hline Don't know & 5 & $\mathbf{4 0}$ \\
\hline Partly trustworthy & $\mathbf{2 0}$ & 25 \\
\hline Not a specified source & 10 & 15 \\
\hline Don't know & $\mathbf{6 5}$ & $\mathbf{3 5}$ \\
\hline Untrustworthy & 45 & 30 \\
\hline Not specified source & 20 & 5 \\
\hline $\begin{array}{l}\text { Inappropriate presentation } \\
\text { of information }\end{array}$ & & \\
\hline
\end{tabular}

Source: Authors.

The results in Table 5 show that the so-called grey zone of media content (which is supplied by state institutions, business companies, and other interest groups-in our case, by the state institution) was quite difficult to identify and reason as partly trustworthy. This fits for students who took very little part in MIL courses and for students who have participated in several MIL basic courses.

Data in Table 6 indicate a much better readiness on the part of the journalism students to evaluate the content of low-quality news than that of the PA students. Untrustworthy news (unauthorised text with an unnamed source) was identified correctly (with the reasoning of "Not a specified source" and "Inappropriate presentation of information") by $65 \%$ of the journalism students and $35 \%$ of the PA 
students (Table 3). The same reasoning regarding not a specified source was used for the assessment of the untrustworthy news as partly trustworthy by $10 \%$ of the journalism students and $25 \%$ of the PA students. This means that the same reasoning can generate different decisions concerning the quality of the provided news. The data of the survey also show that $15 \%$ of the journalism students and $25 \%$ of the PA students assessed the untrustworthy news as trustworthy. Therefore, it can be claimed that some young persons have not acquired knowledge on how to ascertain the trustworthiness of information and what criteria to apply for this purpose.

\section{Journalism students}

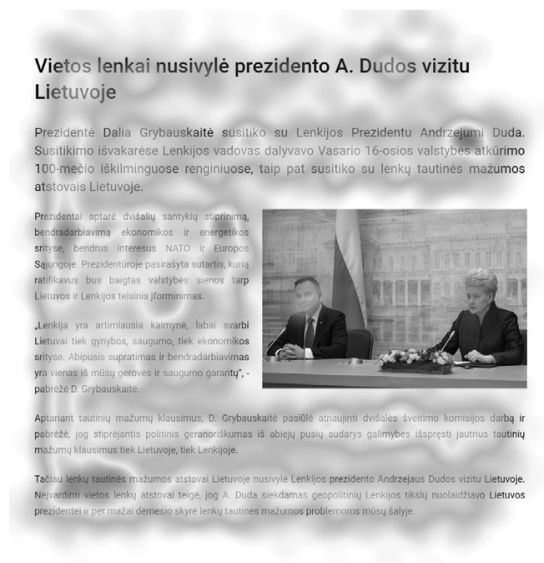

\section{Publishing and advertising students}

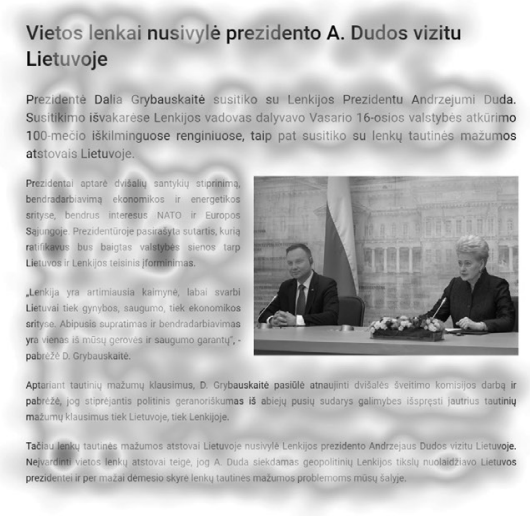

Figure 2. News evaluation heatmaps of both study groups (total reading time)

Eye-tracking equipment allowed to identify the differences between the research groups in the process of news article evaluation. Journalism students who already had some experience in media and information literacy courses were more attentive while reading the articles as they paid more attention to such important news credibility elements as named/unnamed author, photo caption, two sources, etc. PA students were reading news content in a sketchier manner, struggling to identify and find the abovementioned important news credibility elements.

Another notable difference between the research groups is the repeated reading of news content. After reading the news piece for the first time, the respondents came back to some textual elements or photography to perform an in-depth analysis and evaluation. Journalism students who had the previous experience of media literacy courses used repeated reading more frequently. Eye-tracking data evince that journalism students were able to identify important news credibility elements during their first reading and when they came back to check those elements. Meanwhile, PA students used repeated reading less frequently, and, even when doing so, they were paying attention to various elements of the news articles. 


\section{Journalism students}

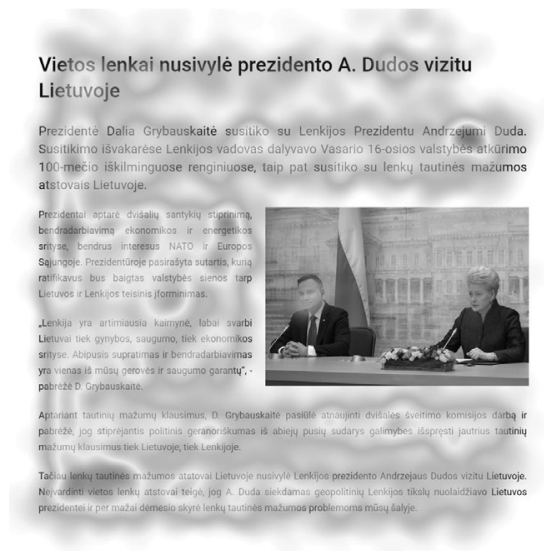

\section{Publishing and advertising students}

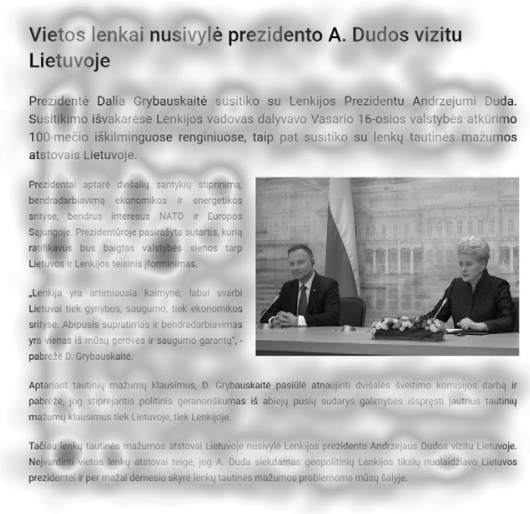

Figure 3. Heatmaps of the final stage of the news evaluation process (only repeated reading)

Research eye-tracking equipment data revealed that both groups of respondents during the evaluation process were paying a significantly larger amount of attention to the text, including the head, lead, and main body of news articles. Meanwhile, photos of the news articles received much less attention. One of the explanations for such responder behaviour could be that Lithuanian President Dalia Grybauskaite is well known and an easily recognisable person in the country, so respondents did not have to spend a lot of time analysing photos.

\section{DISCUSSION AND CONCLUSIONS}

The results of our experiment show a clear difference between two undergraduate student groups and thus point to the importance of media (news) literacy education. Journalism students who had taken various MIL courses showed better news literacy skills in evaluating the trustworthiness of news compared to publishing and advertising students whose learning was minimally related to MIL.

Over the first three semesters, journalism students have four interdisciplinary media literacy courses in their curriculum. These courses serve as a background for media (news) literacy skills that are required to be more critical and to develop a better understanding of the media in general and the role of news in it. However, it is not a guarantee for a good performance (reasonable evaluation of news trustworthiness) in all cases. Some students from the journalism group struggled to evaluate the news articles correctly or to support their assessments clearly and logically. The results of the study show that evaluating the typical state information subsidy material in the news was particularly problematic for both groups of students. Media companies publish single-source press releases for economic 
and organisational reasons, and, in this way, theoretically low-quality content (not meeting the necessary criteria of objectivity) becomes part of mainstream media content in practice. The recognition of such content as credible indicates that some young people (including journalism students) still need to improve their news literacy skills, both to critically evaluate news and also to identify/recognise news.

It is quite obvious that the young people who did not have the knowledge regarding how to ascertain the trustworthiness of information and what criteria to apply had problems in evaluating the news material. Publishing and advertising students not only had problems in evaluating the news content correctly but also had trouble in describing and justifying their arguments. In some cases such arguments like "convincing information" or "information about the head of the state" were used.

The research data collected by the eye-tracking equipment added value to findings regarding the reasoning behind the news evaluation options of the research respondents. Firstly, the eye-tracking data confirmed the survey findings that the journalism student group relied much more on sources than the PA student group when evaluating the trustworthiness of the news. Moreover, the eye-tracking data revealed that the journalism students much more often than the PA students kept their attention on analysing the authorship of the provided messages and photo captions as being important when media users try to answer the main news credibility evaluation questions. Therefore, we can state that eye-tracking equipment can be a useful tool for performing media literacy education research because it allows for the analysis of people's behaviour during the information evaluation process. Being an objective research method with the possibility of reflecting cognitive processing through eye movement metrics, eye tracking is already widely used in various scientific disciplines.

In recent years, it has been possible to observe an increased focus on media literacy education research overall; however, there is still a lack of studies dedicated to specific minor aspects of media literacy education in different countries or regions. Our research underlines the impact of media literacy education on the process of evaluation of news; however, it is important to note that the scope of our research is small, and further research is needed in this area.

\section{REFERENCES}

Ashlock, R. (2011). The influence of media literacy curriculum on body image of postsecondary students in Oklahoma. Doctoral dissertation. Oklahoma State University.

Aufderheide, P., \& Firestone, C. (1993). Media literacy: A report of the national leadership conference on media literacy. Aspen Institute.

Balčytiené, A., \& Juraitė, K. (2017). Media literacy and expanding public spaces cultures, policies and risks in the Baltic countries. In I. Wadbring \& L. Pekkala (Eds.), Citizens in a mediated world. A Nordic-Baltic perspective on media and information literacy (pp. 45-53). Nordicom.

Burnett, C., \& Merchant, G. (2011). Is there a space for critical literacy in the context of social media? English Teaching: Practice and Critique, 10(1), 41-57. https://doi.org/10.1080/146167 0X.2018.1494513. 
Butler, A. (2018). Building media literacy in higher education: Department approach, undergraduate certificate and engaged scholarship. In J. Cubbage (Ed.), Handbook of research on media literacy in higher education environments (pp. 153-171). IGI Global.

Carlson, M. (2018). The information politics of journalism in a post-truth age. Journalism Studies, 19 (13), 1879-1888.

European Commission. (2007). A European approach to media literacy in the digital environment. Communication from the Commission to the European Parliament, the Council, the European Economic and Social Committee and the Committee of the Regions. Brussels, 20.12.2007. COM (2007) 833 final.

Fry, K. G. (2018). Preparing to be digital: The paradigm shift for media studies and higher education. In J. Cubbage (Ed.), Handbook of research on media literacy in higher education environments (pp. 78-89). IGI Global.

Glasser, T. L. (1992). Objectivity and news bias. In E. D. Cohen (Ed.), Philosophical issues in journalism (pp. 176-183). Oxford University Press.

Graves, L. (2016). Deciding what's true: The rise of political fact-checking in American journalism. Columbia University Press.

Hassan, N., Adair, B., Hamilton, J. T., Li, C., Tremayne, M., Yang, J., \& Yu, C. (2015). The quest to automate fact-checking. Proceedings of the 2015 Computation + Journalism Symposium. http:// ranger.uta.edu/ cli/pubs/2015/claimbuster-cj15-hassan.pdf.

Hobbs, R. (1998). The seven great debates in the media literacy movement. Journal of Communication, 48, 16-32. https://doi.org/10.1111/j.1460-2466.1998.tb02734.x.

Hobbs, R. (2005). Media literacy and the K-12 content areas. In S. Gretchen, \& P. U. Brown (Eds.), Media literacy: Transforming curriculum and teaching (pp. 74-99). Blackwell.

Hobbs, R. (2010). News literacy: What works and what doesn't. Paper presentation at the Association for Education in Journalism and Mass Communication (AEJMC) Conference, Denver, Colorado, August 7, 2010.

Hobbs, R. (2011). What a difference ten years can make: Research possibilities for the future of media literacy education. Journal of Media Literacy Education, 3(1), 29-31.

Hovland, C. I., Janis, I. L., \& Kelley, J. J. (1953). The influence of source credibility on communication effectiveness. Public Opinion Quarterly, 15, 635-650. https://doi.org/10.1086/266350.

Kellner, D., \& Share, J. (2005). Media literacy in the US. MedienPädagogik: Zeitschrift für Theorie Und Praxis Der Medienbildung, 11, 1-21. https://doi.org/10.21240/mpaed/11/2005.09.15.X.

Kellner, D. \& Share, J. (2007). Critical media literacy is not an option. Learning Inquiry, 1(1), 59-69. https://doi.org/10.1007/s11519-007-0004-2.

Koltay, T. (2011). The media and the literacies: Media literacy, information literacy, digital literacy. Media, Culture \& Society, 33(2), 211-221. https://doi.org/10.1177/0163443710393382.

Lilleker, D. G. (2006). Key concepts of political communication. Sage Publications.

Livingstone, S. (2004). Media literacy and the challenge of new information and communication technologies. The Communication Review, 7(1),3-14. https://doi.org/10.1080/10714420490280152

Maras, S. (2013). Objectivity in journalism. Polity Press.

Malik, M., Cortesi, S., \& Gasser, U. (2013). The challenges of defining "news literacy." Berkman Center for Internet \& Society.

Martens, H. (2010). Evaluating media literacy education: Concepts, theories and future directions. Journal of Media Literacy Education, 2(1), 1-22.

Masterman, L. (1985). Teaching the media. Routledge.

McQuail, D. (2010). McQuail's mass communication theory (6th edition). Sage Publications.

Messaris, P. (1994). Visual literacy: Image, mind and reality. Westview Press.

Metzger, M. J., Flanagin, A. J., Eyal, K., Lemius, D. R., \& McCann, R. M. (2003). Credibility for the 21st century: Integrating perspectives on source, message, and media credibility in the contemporary media environment. Annals of the International Communication Association, 27(1), 293-335. https://doi.org/10.1080/23808985.2003.11679029. 
Mihailidis, P. (2006). Media literacy in journalism/mass communication education: Can the United States learn from Sweden? Journalism \& Mass Communication Educator, 60(4), 416-428. https:// doi.org/10.1177/107769580506000409.

Mihailidis, P. (2008). Beyond cynicism: How media literacy can make students more engaged citizens Doctoral dissertation. University of Maryland.

Nguyen, T.T., Weidlich, M., Yin, H., Zheng, B., Nguyen, Q., \& Stantic, B. (2019). User guidance for efficient fact checking. Proceedings of the VLDB Endowment, 12(8), 850-863.

Onge, J. St. (2018). Teaching media literacy from a cultural studies perspective. In J. Cubbage (Ed.), Handbook of research on media literacy in higher education environments (pp. 136-152). IGI Global.

Order of the Minister of Education and Science of the Republic of Lithuania No V-442. TAR [Register of legislation], 2017-06-05, No 9553.

Potter, W. J. (2008). Media literacy (4th edition). Sage Publications.

Potter, W. J. (2010). The state of media literacy. Journal of Broadcasting \& Electronic Media, 54(4), 675-696. https://doi.org/10.1080/08838151.2011.521462.

Sakadolskis, R. (2007). Kaip kritiškai skaityti laikrašti ir kam to reikia? [How do read a newspaper critically and who needs it?]. In R. Juozapavičius (Ed.), Žiniasklaidos skaidrumas [Media Transparency] (pp. 42-54). Eugrimas.

Schmidt, H. C. (2012). Media literacy education at the university level. The Journal of Effective Teaching, 12(1), 64-77.

Schmidt, H. C. (2013). Media literacy education from kindergarten to college: A comparison of how media literacy is addressed across the educational system. Journal of Media Literacy Education, 5(1), 295-309.

Shi, B., \& Weninger, T. (2016). Fact checking in heterogeneous information networks. WWW, 16 Companion: Proceedings of the 25th International Conference Companion on World Wide Web, $101-102$.

Street, B. (1984). Literacy in theory and practice. Cambridge University Press.

Tanz, J. (2017). Journalism fights for survival in the post-truth era. Wired, 14 February 2017. https:// www.wired.com/2017/02/journalism-fights-survival-post-truth-era/.

Thoman, E. (1995). Operational definition of media literacy. Center for Media Literacy.

Wan, G. (2006). Integrating media literacy into the curriculum. Academic Exchange Quarterly, 10(3), 174.

Wan, G., \& Gut, D.M. (2008). Media use by Chinese and U.S. Secondary Students: Implications for media literacy education. Theory into Practice, 47, 178-185.

Westerstahl, J. (1983). Objective news reporting. Communication Research, 10(3), 403-424. https:// doi.org/10.1177/009365083010003007. 